\title{
Post-Multifibre Arrangement Analysis of the Textile and Garment Sectors in Kenya
}

\author{
Dorothy McCormick, Paul Kamau and Peter Ligulu
}

\section{Introduction}

The textile and clothing industry represents a vital source of income for developing countries. World trade in textiles and clothing constitutes almost US\$400bn - nearly 10 per cent of all trade in manufactured goods. A major proportion of these exports comes from developing countries, including more than 70 per cent of all apparel exports, making the sector a vital source of employment, income and foreign exchange revenues. Globally, tens of millions of people work in textiles and clothing, more than two-thirds of whom are located in Asia (Oxfam 2004, Appelbaum 2004). It is estimated that nearly three-quarters of all workers in the garment industry are women.

Until the end of 2004, the world's largest importers of textiles and clothing protected their markets through a restrictive system of Multifibre Arrangement (MFA) import quotas, combined with high tariffs. Further, the restrictions curtailed the ability of developing countries to generate sorely needed employment opportunities in these labour-intensive sectors (Kathuria et al. 2001; Smith 1996). To partly offset this restrictive regime, developed countries designed mechanisms to allow selected countries to access their markets under preferential arrangements. Such regimes include the US' African Growth and Opportunity Act (AGOA) and the European Union's African Caribbean and Pacific (ACP-EU) under the Lomé Convention and Cotonou Agreement, and the Everything-But-Arms (EBA), among others.

The MFA termination at the end of 2004 has generated concern in those countries that were enjoying preferential market access regimes. They worry mainly about the level of competition expected from large Asian countries that have established textile and clothing industries. These countries, called Asian Drivers in this IDS Bulletin, are capable of producing the large volumes at low prices. By some estimates, China alone has the potential to supply 50 per cent of the world's total demand for textiles and clothing. Can relatively small exporters like Kenya hope to compete in the US market against such giants? This article attempts to provide some preliminary answers to this question. It also raises issues that need further investigation as Kenya considers a post-MFA strategy for the development of the textile and clothing sector.

The overall objective of this article is to assess the impact of Asian Drivers on the Kenyan textile and clothing sector. The article begins by a brief description of AGOA and MFA. It then examines their effects on the Kenyan textile and clothing industry, using export data for the period 2000-05. The article continues to highlight the challenges currently facing the industry, and finally draws conclusions, and lists some emerging issues.

The article uses data from a set of interviews conducted among stakeholders in the Kenyan textile and clothing sectors. The informants included government ministries, export and investment promotion agencies, business associations, labour unions and the economic sections of two Asian embassies. These were supplemented by literature review and a variety of secondary data.

\section{Access to the US market through AGOA}

AGOA became law on 18 May 2000 as Title 1 of 'The US Trade and Development Act of 2000'. The Act offers tangible incentives for sub-Sahara African (SSA) countries to continue their efforts to open

IDS Bulletin Vol 37 No 1 January 2006 ㄷ Institute of Development Studies 
their economies and build free markets. As a nonreciprocal trade agreement between the US and African countries, AGOA is partially designed to lay the foundation for creation of US Free Trade Agreements (FTAs) with SSA countries. At the signing ceremony, President Bill Clinton noted that the legislation would expand 'Africa's access to our markets and improve the ability of African nations to ease poverty, increase growth, and heal the problems of its people'. AGOA significantly liberalised trade between the US and 37 SSA countries by reducing tariff and non-tariff barriers to trade. The Act originally covered the eight-year period from October 2000 to September 2008 but amendments signed into law by US President George Bush in July 2004 further extend AGOA to 2015. At the same time, a special dispensation relating to apparel was extended by three years to September 2007.

AGOA builds on existing US trade programmes by expanding the benefits previously available only under the Generalised System of Preferences (GSP) programme. Duty-free access to the US market under the combined AGOA/GSP programme now stands at approximately 7,000 product tariff lines, including the roughly 1,800 product tariff lines that were added to the GSP by the AGOA legislation. Included in the legislation are items such as: textile, apparel and footwear, wine, certain motor vehicle components, agricultural products, chemicals and steel and petroleum products. ${ }^{1}$ For Kenya, textiles and apparel are the most important AGOA exports (see Appendix 1).

In order to benefit from AGOA, African governments must adhere to the eligibility requirements outlined in s. 104 of the Act. These include progress towards: (1) establishing a marketbased economy, protection of private property, and open rules-based trading system; (2) maintaining the rule of law; (3) removing barriers to US trade and investment; (4) policies to reduce poverty; (5) policies to combat corruption; and (6) compliance with the rights of workers recognised internationally. AGOA eligibility does not automatically imply eligibility to export apparel products, which requires implementation of an effective visa system and an enforcement mechanism to prevent illegal transshipment. Duty-free access for apparel is subject to three other conditions. First, there is unlimited access for apparel made in eligible SSA countries using fabric, yarn and thread from the US. Second, AGOA imposes a cap of 1.5 per cent of overall US apparel imports limited to 3.5 per cent over an eight-year period for apparel made from African manufactured fabric and yarn. Finally, under preferential rule, SSA countries with per capita gross national product (GNP) of less than US $\$ 1,500$ in 1998 enjoyed duty-free access until 30 September 2004, for apparel made from fabric originating anywhere in the world (Salm et al. 2004: 11). This preferential treatment has since been extended to September 2007, after which continued duty-free access to the US will be limited to apparel made from fabric produced locally, in another AGOA beneficiary, or the US itself.

Kenya was the first SSA country to qualify for the AGOA 'Wearing Apparel' provisions on 18 January 2001. This is important for two reasons. First, the quick development of the necessary visa system shows the commitment of the Kenyan government to what it rightly perceived to be an important opportunity to strengthen exports. Second, early qualification has allowed the industry to accumulate nearly five years of experience, during which it has had opportunities to improve production systems, build networks in export markets, and develop related export competencies.

Kenya's main exports under AGOA are cotton shirts and trousers made from imported fabric, in large factories. The country also exports a limited quantity of hand-woven apparel and other textile products under 'Category 9' of AGOA. Category 9 includes handloom, handmade textiles and folklore products. These have unlimited duty-free access to the US market, provided that they meet AGOA's specific requirements regarding, for example, the authenticity of the traditional folklore articles. Category 9 could give Kenya an avenue for exporting the products made by micro and small enterprises. A major problem however, is that most producers of category-9-eligible items lack the entrepreneurial and technical skills needed both to make products of consistent quality and to undertake the various processes required to get them to buyers on time.

\section{The end of MFA}

The MFA and its related World Trade Organization (WTO) Agreements on Textiles and Clothing (ATC) set specific rules governing international trade in clothing and textiles by WTO member countries. The MFA, in effect since 1974, provided a framework under which developed countries 
Table 1: Export of textile and clothing

\begin{tabular}{lllllll}
\hline Year & $\begin{array}{l}\text { Factories } \\
(\boldsymbol{n})\end{array}$ & $\begin{array}{l}\text { Employees } \\
(\boldsymbol{n})\end{array}$ & $\begin{array}{l}\text { Export quantity } \\
\text { (pieces) }\end{array}$ & $\begin{array}{l}\text { Export value } \\
(\mathbf{U S} \mathbf{\text { ) }}\end{array}$ & $\begin{array}{l}\text { Visas issued } \\
(\boldsymbol{n})\end{array}$ & $\begin{array}{l}\text { Average unit } \\
\text { price (US\$) }\end{array}$ \\
\hline 2000 & 10 & 10,000 & $6,057,370$ & $30,173,792$ & 983 & 4.96 \\
2001 & 15 & 16,000 & $14,548,266$ & $70,095,508$ & 1060 & 4.82 \\
2002 & 25 & 26,000 & $28,615,384$ & $119,907,104$ & 1986 & 4.19 \\
2003 & 40 & 37,000 & $41,463,230$ & $178,384,134$ & 2979 & 4.30 \\
2004 & 36 & 32,000 & $61,320,109$ & $261,214,768$ & 4185 & 4.26 \\
2005 June & 22 & 25,000 & $31,220,221$ & $114,118,369$ & 1659 & 3.66 \\
Total & & & $177,167,210$ & $743,719,883$ & 11,869 & 4.39 \\
\hline
\end{tabular}

Source: own data.

including the US, the EU and Canada, imposed quotas on exports of textiles and apparel from developing countries (Bagchi 2001). The US, as one of the largest importers of textiles, maintained quotas on textiles and apparel from 46 countries, compared with the EU's 21 (Elbehri 2004).

The overall effect of these quotas was to increase prices in importing countries and to suppress the growth of exports in many developing countries (Trela and Whalley 1990; Bagchi 2001). In particular cases, however, developing countries benefited from the quotas imposed on others. For example, the development of the Mauritian garment industry happened to some extent because several countries imposed quotas on Hong Kong, which prompted Hong Kong textile and clothing investors to look for alternative production sites (Cable 1990).

Developing countries began to call for the end of the MFA as early as 1980. Initial attempts were met with resistance but in 1995 the Uruguay Round negotiated the Agreement on Textiles and Clothing (ATC). This provided for a ten-year phasing-out of the MFA and its ultimate termination on 31 December 2004. Without MFA quotas, buyers in importing countries have strong incentives to source from the cheapest producers. ${ }^{2}$ The most immediate beneficiary of this strategy is China. Other Asian countries are also likely to benefit, though probably to a lesser extent than China. The losers will be high-cost producers whose market access has been facilitated by the quotas placed on others. They will find themselves pushed by buyers to reduce unit costs.

It is therefore important to note that the cost to the buyer includes import duties as well as production costs. Preferential agreements such as
AGOA, therefore, help to mitigate the effects of the MFA phase-out by narrowing the cost gap between Asian and African producers. Although tariffs vary by type of garment and fabric used, the items that Kenya most commonly exports to the US carry tariffs in the range of 16-20 per cent, effectively allowing its apparel factories leeway for higher costs (see Appendix 2).

\section{Kenya, AGOA and the end of MFA}

Export data for the period 2000-mid-2005 reveal the combined impact of AGOA and the MFA on Kenyan textile and clothing exports (see Table 1). It is estimated that over 90 per cent of Kenya's exports to the US market are produced within the Export Processing Zones (EPZA 2005). The value of textile and clothing exports rose from US $\$ 30 \mathrm{~m}$ in 2000 to US $\$ 261 \mathrm{~m}$ in 2004 , the highest since AGOA was enacted. The highest growth rate was recorded between 2000 and 2001, when exports rose 133 per cent from US $\$ 30$ to $70 \mathrm{~m}$. Growth fell to 81 per cent and 40 per cent in 2002 and 2003, respectively, then increased to 46 per cent in 2004. By June 2005, textiles and clothing worth US $\$ 114 \mathrm{~m}$ had been exported to the US under AGOA.

The number of textile and clothing firms also grew from ten in 2000 to 36 in 2004. By June 2005, their number had declined to 22 for reasons largely connected to the end of the MFA. Related to this is the value of investment which has increased from US $\$ 83 \mathrm{~m}$ in 2000 to US $\$ 233 \mathrm{~m}$ in 2004 . Between 2000 and 2004 a growth rate of almost 200 per cent in investment was realised. Export processing zone (EPZ) gazetted zones also increased from 19 to 41 between 2000 and 2004. 
In 2000, the EPZs had 10,000 employees in the textile and clothing sector alone. With the enactment of AGOA, this figure peaked at 40,000 in mid-2004. However, by the end of 2004, this had declined to 32,000 and only 25,000 by June 2005 .

Despite the falling employment and firm closures, production levels in the first half of 2005 are comparable with those of a year earlier. The average unit price has however dropped from US\$4.26 in 2004 to only US\$3.66 in 2005. According to some informants, this is the result of pressure by US buyers that want factories to reduce prices by 25 per cent as a condition for continued orders. Despite the loss of both factories and workers, production appears to be holding almost steady.

By June 2005, export quantities were slightly higher than those for the same period in 2004. Nevertheless, it is clear that the end of MFA has had a negative impact on Kenya's exports of textiles and clothing. For instance, the number of visas issued suggests that Kenyan firms have received fewer orders from the US in 2005. Some respondents confirmed that, unlike previous years, firms do not have orders beyond 2005.

Kenyan firms wishing to continue exporting to the US are under considerable pressure to reduce costs. One reason is clearly the rising competition in the US market due to the increased presence of garments from the Asian Drivers. Although Asian Drivers pay tariffs for their exports to the US, their efficiency and low production costs make them highly competitive even with duty-free imports. In addition, the US has recently concluded many FTAs with other regions. This will bring additional duty-free imports that will further intensify the competition for AGOAeligible countries.

\section{Challenges resulting from the ending of the MFA}

The ending of MFA has had diverse implications for the Kenyan textile and clothing sector. The market environment has been tilted with the emergence of Asian Drivers as major suppliers to the US market. The biggest challenge has been China, which it is claimed can 'clothe half of the world' and other Asian producers like India, Sri Lanka, Vietnam and Bangladesh. The increased competition has led to new requirements by the US buyers on Kenyan producers. It has also highlighted differences between Kenya and the Asian Drivers which have clear bearing on Kenya's competitiveness. Among these are labour costs, the structure of employment, infrastructure and government support.

There is a significant difference between labour cost in Kenya and Asian countries. Since the textile and clothing industry is to a large extent labour intensive, the cost of labour is an important ingredient in production cost and efficiency (Nadvi et al. 2004). Wages in the Kenyan textile and clothing industry are higher than those in China and India. One reason for this is Kenya's higher cost of living. Nevertheless, the high cost of labour impedes the competitiveness of the industry especially when compared with Asian Drivers. Surprisingly, despite increased global competition and pressures to reduce prices, there has not been wage decline in the Kenyan textile and clothing industry. ${ }^{3}$ EPZ firms in Kenya have sought government support to peg minimum wages on productivity so as to enhance their efficiency.

A second challenge concerns the structure of employment. The rapid growth of employment in the EPZ over the last four years has had significant impact on the structure of the Kenya's formal employment. As discussed by Kaplinsky (2004), in 2003 the EPZ accounted for 18.7 per cent of total private formal sector manufacturing employment rising from 7.5 per cent and 2.8 per cent in 1995 and 1997 , respectively. The increasing importance of EPZ in generating formal employment makes the current downturn an issue of policy concern.

A third challenge relates to the differences in the state of infrastructure between Kenya and Asian Drivers. To start with, the cost of energy in Kenya is almost double that of Asian Drivers. In addition, the power supply in Kenya is coupled with failures and interruptions, which greatly affect production especially within the textile sector. Kenya's railway network is not as developed as that of China and India, making the cost of transporting either raw materials or finished products expensive. The road network which would provide an alternative means of transportation in the absence of railway transport is fast becoming degraded. Another area of concern is the cost and availability of communication facilities. Most investors have echoed the high cost that firms incur in accessing communication facilities. ${ }^{4}$ In summary, the lack of adequate supply of infrastructure pushes the cost of production up.

The final and perhaps most important difference between Kenya and the Asian Drivers is the level of support from government. Kenya is attempting 
to improve procedures that affect business but business registration and customs clearance remain time-consuming and costly to manufacturing firms. In most cases, to register a business, one needs more than 30 days for the documentation alone. Clearing customs whether one is importing or exporting can take as long as 22 days. In contrast, these processes have been shortened and made more efficient in both China and India.

Some informants claimed that India and China have direct and indirect subsidies that result in competitive advantage over Kenyan manufacturers. For instance, China's currency (Yuan) has been fixed at 8.28 against the US dollar for many years. Competing countries have argued that the currency has been undervalued, resulting in cheaper exports that give China an unfair advantage (see also Nathan Associates 2004: 29). It was only on 21 July 2005 that China raised the value of Yuan to 8.11 to the US dollar. However, this revaluation of only 2.1 per cent is unlikely to have a significant impact on China's exports. Also, India has a programme that supports textile upgrading by providing subsidised interest rates on loans and capital equipment. Kenya lacks such schemes that would give its manufacturers equal footing to those of Asian Drivers.

Asian countries have been major suppliers of fabric to Kenyan textile and clothing industry. It is possible that with their expanded markets due to MFA termination, the supply of the fabric to the Kenyan industry will be constrained. However, a firm conclusion on this issue would require additional data.

More importantly, Kenya's progress has been hampered by a lack of public-private sector dialogue on the way forward for the textile and clothing industry. Most of those concerned have adopted a "wait and see" attitude in the hope that international organisations will come to rescue the industry.

A further challenge is the multiplication of FTAs. When AGOA was enacted, there were only two US FTAs that allowed duty-free access to the US market.

\section{Notes}

1. For a more detailed discussion of AGOA, see US Congress (2000), Lee (2004) and Salm et al. (2004).

2. For a more detailed discussion on how buyers are likely to change their buying patterns, see Appelbaum (2004) and Nathan Associates (2004).

3. Wages paid in the Kenyan textile and clothing firms are well above the government minimum wages, see EPZA (2005).
By the end of 2004, the US has enacted more than ten FTAs with other regions of the world. While this is good for advancing the free trade agenda, it has created a serious challenge for AGOA-eligible countries like Kenya, which will have to face stiffer competition.

\section{Conclusions and emerging issues}

This study finds that the passage of AGOA enabled Kenya to increase exports and attract significant new investment between 2000 and 2004. The decline of about 15 per cent in the average unit price over the same period suggests that the industry was becoming more efficient and that firms were "learning by exporting". ${ }^{5}$ Until September 2007, the remaining fairly efficient firms may be able to continue producing for export to the US using AGOA's provision for use of third-party fabric. However, beyond this date, this will not be an option as the more stringent rules of origin take effect. This is a major challenge for Kenya because although the country's textile industry can produce good quality fabric, it cannot do so at prices comparable with those in East Asian countries.

The new challenges created by the end of the MFA are forcing a re-thinking of the strategy for the industry. The push for lower costs and the emergence of multiple FTAs have heightened competition in the US market. Supply constraints will also make continued participation in AGOA difficult. So what can Kenya do? One option is to lobby for further extension of the present exemption to the rules of origin. Since success in this is uncertain, Kenya also needs to think strategically in other directions. Developing a new strategy for these industries will involve looking at many options, including regional approaches, greater attention to infrastructure, and access to niche markets such AGOA's category 9. Whatever approach is taken, it is clear that success will depend on public and private sectors working together to smooth the bumpy post-MFA road.

4. This concurs with the findings of IDS (2004) where the cost of doing business in Kenya was identified as being very high.

5. There is a fairly wide literature on "learning by exporting"; see Fernandes and Isgut (2005) for a summary. 


\section{References}

AGOA, 2005, Bilateral Trade Between United States and Kenya, www.a goa.info/?view=country_info \&country=ke (accessed 12 September 2005)

Appelbaum, R.C., 2004, 'Assessing the impact of the phasing-out of the agreement on textile and clothing on apparel exports on the least developed and developing countries', Global and International Studies Program Paper 33, Santa Barbara: University of California

Bagchi, S., 2001, International Trade Policy in Textiles: Fifty Years of Protectionism, Geneva: International Textiles and Clothing Bureau

Cable, V., 1990, 'Adjusting to Textile and Clothing Quotas: A Summary of Some Commonwealth Countries' Experiences as a Pointer to the Future', in C.B. Hamilton (ed.), Textiles Trade and the Developing Countries: Eliminating the Multi-Fibre Arrangement in the 1990s, Washington, D.C.: World Bank

Elbehri, A., 2004, 'MFA quota removal and global textile and cotton trade: estimating quota trade restrictiveness and quantifying post-MFA trade patterns', paper prepared for 7 th Annual Conference on Global Economic Analysis, Washington, D.C., 17-19 June 2004

Export Processing Zones Authority (EPZA), 2005, Contribution of EPZ into the Kenyan Economy, www.epzakenya.com (accessed 10 September 2005)

Fernandes, A.M. and Isgut, A., 2005, 'Learningby-doing, learning-by-exporting, and productivity: evidence from Colombia', paper presented at a conference on 'Dynamics, Economic Growth, and International Trade' organised by Centro de Investigacion y Docencia Economicas (CIDE) and the Copenhagen Business School, Mexico City, Mexico, 3-4 June 2005

IDS, 2004, 'Prospects for competitiveness and productivity growth of garment industry in Kenya', Final Report Submitted to IDE-JETRO, Nairobi: Institute for Development Studies
Kaplinsky, R., 2004, 'Background notes for UNCTAD investment policy review: Kenya', mimeo, Brighton: Institute of Development Studies

Kathuria, S., Martin, W. and Bharddwaj A., 2001, 'Implications for South Asian countries of the abolishing the Multifibre Arrangement', Working Paper Series No 2721, Washington, D.C.: World Bank

Kenya Association of Manufacturers, 2005, Exports of Apparel and Textiles in Kenya, www.kam.co.ke/ entArt. asp? cat $=$ sectors\&sid $=30$ (accessed 15 September 2005)

Lee, C.M., 2004, 'America's trade adventure in Africa: AGOA and the implications of a US-SACU FTA', Africa Institute Occasional Paper 73

Nadvi, K. and Thoburn, J.T, 2004, 'Vietnam in the global garment and textile value chain: impacts on firms workers', Journal of International Development, Vol 16 No 1: 111-23

Nathan Associates, 2004, 'Dominican Republic textile and apparel export competitiveness', Trade and Industry Final Report submitted to USAID, November

Oxfam, 2004, 'Stitched up: how rich country protectionism in textiles and clothing trade prevents poverty alleviation', Oxfam Briefing Paper 60, April

Salm, A.W., Grant, W., Haycock, J. and Kennedy K., 2004, 'Botswana textile and apparel subsector study', Research Report submitted to ComMark Trust, Collo Manor

Smith, D., 1996, 'Going South: global restructuring and garment production in the East Asian cases', Asian Perspective, Vol 20 No 2: 211-41

Trela, I. and Whalley, J., 1990, 'Unravelling the Threads of the MFA,' in C.B. Hamilton (ed.), Textiles Trade and the Developing Countries: Eliminating the Multi-Fibre Arrangement in the 1990s, Washington, D.C.: World Bank

US Congress, 2000, Trade and Development Act of 2000, 24 January 
IDS Bulletin 37.1 Asian Drivers: Opportunities and Threats

Appendix 1: Bilateral trade between United States and Kenya

\begin{tabular}{|c|c|c|c|c|c|}
\hline & \multicolumn{3}{|c|}{ Value (US\$1000) } & \multicolumn{2}{|c|}{$\begin{array}{l}\text { Year-to-date (YTD) } \\
\text { (January-June) }\end{array}$} \\
\hline & 2002 & 2003 & 2004 & 2004 YTD & 2005 YTD \\
\hline \multicolumn{6}{|l|}{ Agricultural products: } \\
\hline US exports to Kenya & 42,698 & 32,848 & 35,871 & 12,448 & 20,336 \\
\hline US imports from Kenya & 40,012 & 41,906 & 50,935 & 23,586 & 30,874 \\
\hline $\begin{array}{l}\text { Total AGOA including GSP provisions } \\
\text { of AGOA }\end{array}$ & 2860 & 5309 & 11,124 & 4339 & 2101 \\
\hline US imports under GSP from Kenya & 1248 & 1033 & 2995 & 1329 & 581 \\
\hline $\begin{array}{l}\text { US imports of duty-free items added } \\
\text { under AGOA }\end{array}$ & 1613 & 4276 & 8129 & 3011 & 1520 \\
\hline \multicolumn{6}{|l|}{ Forest products: } \\
\hline US exports to Kenya & 3214 & 2834 & 3857 & 2177 & 2748 \\
\hline US imports from Kenya & 3358 & 1810 & 1979 & 881 & 1056 \\
\hline $\begin{array}{l}\text { Total AGOA including GSP provisions } \\
\text { of AGOA }\end{array}$ & 2448 & 1582 & 1556 & 664 & 439 \\
\hline US imports under GSP from Kenya & 2448 & 1575 & 1552 & 663 & 438 \\
\hline $\begin{array}{l}\text { US imports of duty-free items added } \\
\text { under AGOA }\end{array}$ & 0 & 6 & 5 & 0 & 1 \\
\hline \multicolumn{6}{|l|}{ Chemicals and related products: } \\
\hline US exports to Kenya & 32,604 & 32,447 & 31,505 & 14,801 & 16,294 \\
\hline US imports from Kenya & 2394 & 1552 & 3111 & 1601 & 2182 \\
\hline $\begin{array}{l}\text { Total AGOA including GSP provisions } \\
\text { of AGOA }\end{array}$ & 734 & 153 & 948 & 370 & 643 \\
\hline US imports under GSP from Kenya & 104 & 153 & 948 & 370 & 643 \\
\hline $\begin{array}{l}\text { US imports of duty-free items added } \\
\text { under AGOA }\end{array}$ & 631 & 0 & 0 & 0 & 0 \\
\hline \multicolumn{6}{|l|}{ Energy-related products: } \\
\hline US exports to Kenya & 188 & 258 & 834 & 472 & 117 \\
\hline US imports from Kenya & 0 & 76 & 271 & 271 & 0 \\
\hline $\begin{array}{l}\text { Total AGOA including GSP provisions } \\
\text { of AGOA }\end{array}$ & 0 & 0 & 0 & 0 & 0 \\
\hline US imports under GSP from Kenya & 0 & 0 & 0 & 0 & 0 \\
\hline $\begin{array}{l}\text { US imports of duty-free items added } \\
\text { under AGOA }\end{array}$ & 0 & 0 & 0 & 0 & 0 \\
\hline \multicolumn{6}{|l|}{ Textiles and apparel: } \\
\hline US exports to Kenya & 7594 & 7260 & 9470 & 4664 & 3553 \\
\hline US imports from Kenya & 126,488 & 188,148 & 277,432 & 129,209 & 134,560 \\
\hline $\begin{array}{l}\text { Total AGOA including GSP provisions } \\
\text { of AGOA }\end{array}$ & 121,881 & 176,286 & 271,580 & 125,774 & 131,387 \\
\hline US imports under GSP from Kenya & 10 & 8 & 97 & 32 & 28 \\
\hline $\begin{array}{l}\text { US imports of duty-free items added } \\
\text { under AGOA }\end{array}$ & 121,870 & 176,278 & 271,483 & 125,742 & 131,359 \\
\hline \multicolumn{6}{|l|}{ Footwear: } \\
\hline US exports to Kenya & 87 & 242 & 266 & 109 & 58 \\
\hline US imports from Kenya & 33 & 10 & 294 & 55 & 22 \\
\hline $\begin{array}{l}\text { Total AGOA including GSP provisions } \\
\text { of AGOA }\end{array}$ & 6 & 9 & 27 & 25 & 20 \\
\hline
\end{tabular}


Appendix 1 (Cont.)

\begin{tabular}{|c|c|c|c|c|c|}
\hline & \multicolumn{3}{|c|}{ Value (US\$1000) } & \multicolumn{2}{|c|}{$\begin{array}{l}\text { Year-to-date (YTD) } \\
\text { (January-June) }\end{array}$} \\
\hline & 2002 & 2003 & 2004 & 2004 YTD & 2005 YTD \\
\hline \multicolumn{6}{|l|}{ Footwear (cont.) } \\
\hline US imports under GSP from Kenya & 0 & 0 & 0 & 0 & 0 \\
\hline $\begin{array}{l}\text { US imports of duty-free items added } \\
\text { under AGOA }\end{array}$ & 6 & 9 & 27 & 25 & 20 \\
\hline \multicolumn{6}{|l|}{ Minerals and metals: } \\
\hline US exports to Kenya & 10,805 & 8521 & 31,191 & 13,881 & 11,579 \\
\hline US imports from Kenya & 1592 & 1236 & 1608 & 698 & 858 \\
\hline $\begin{array}{l}\text { Total AGOA including GSP provisions } \\
\text { of AGOA }\end{array}$ & 530 & 247 & 181 & 37 & 112 \\
\hline US imports under GSP from Kenya & 321 & 247 & 181 & 37 & 112 \\
\hline $\begin{array}{l}\text { US imports of duty-free items added } \\
\text { under AGOA }\end{array}$ & 209 & 0 & 0 & 0 & 0 \\
\hline \multicolumn{6}{|l|}{ Machinery: } \\
\hline US exports to Kenya & 10,071 & 15,162 & 15,346 & 6861 & 24,112 \\
\hline US imports from Kenya & 503 & 297 & 318 & 232 & 157 \\
\hline $\begin{array}{l}\text { Total AGOA including GSP provisions } \\
\text { of AGOA }\end{array}$ & 45 & 39 & 5 & 0 & 10 \\
\hline US imports under GSP from Kenya & 45 & 39 & 5 & 0 & 10 \\
\hline $\begin{array}{l}\text { US imports of duty-free items added } \\
\text { under AGOA }\end{array}$ & 0 & 0 & 0 & 0 & 0 \\
\hline \multicolumn{6}{|l|}{ Transportation equipment: } \\
\hline US exports to Kenya & 123,895 & 64,246 & 210,187 & 199,618 & 423,279 \\
\hline US Imports from Kenya & 179 & 183 & 274 & 146 & 553 \\
\hline $\begin{array}{l}\text { Total AGOA including GSP provisions } \\
\text { of AGOA }\end{array}$ & 0 & 0 & 13 & 0 & 0 \\
\hline US imports under GSP from Kenya & 0 & 0 & 13 & 0 & 0 \\
\hline $\begin{array}{l}\text { US imports of duty-free items added } \\
\text { under AGOA }\end{array}$ & 0 & 0 & 0 & 0 & 0 \\
\hline \multicolumn{6}{|l|}{ Electronic products: } \\
\hline US exports to Kenya & 23,217 & 18,871 & 35,713 & 15,721 & 23,242 \\
\hline US imports from Kenya & 4357 & 6128 & 3271 & 1129 & 1598 \\
\hline $\begin{array}{l}\text { Total AGOA including GSP provisions } \\
\text { of AGOA }\end{array}$ & 8 & 43 & 19 & 18 & 48 \\
\hline US imports under GSP from Kenya & 6 & 43 & 18 & 18 & 8 \\
\hline $\begin{array}{l}\text { US imports of duty-free items added } \\
\text { under AGOA }\end{array}$ & 2 & 0 & 1 & 0 & 40 \\
\hline \multicolumn{6}{|l|}{ Miscellaneous manufactures: } \\
\hline US exports to Kenya & 1907 & 1388 & 2094 & 659 & 736 \\
\hline US imports from Kenya & 2333 & 2508 & 2714 & 1315 & 1052 \\
\hline $\begin{array}{l}\text { Total AGOA including GSP provisions } \\
\text { of AGOA }\end{array}$ & 698 & 774 & 1234 & 546 & 359 \\
\hline US imports under GSP from Kenya & 693 & 744 & 982 & 406 & 308 \\
\hline $\begin{array}{l}\text { US imports of duty-free items added } \\
\text { under AGOA }\end{array}$ & 6 & 30 & 253 & 140 & 50 \\
\hline
\end{tabular}


IDS Bulletin 37.1 Asian Drivers: Opportunities and Threats

Appendix 1 (Cont.)

\begin{tabular}{|c|c|c|c|c|c|}
\hline & \multicolumn{3}{|c|}{ Value (US\$1000) } & \multicolumn{2}{|c|}{$\begin{array}{l}\text { Year-to-date (YTD) } \\
\text { (January-June) }\end{array}$} \\
\hline & 2002 & 2003 & 2004 & 2004 YTD & 2005 YTD \\
\hline \multicolumn{6}{|l|}{ Special provisions: } \\
\hline US exports to Kenya & 11,692 & 8932 & 10,604 & 5485 & 11,526 \\
\hline US imports from Kenya & 7906 & 5282 & 9959 & 4843 & 1484 \\
\hline $\begin{array}{l}\text { Total AGOA including GSP provisions } \\
\text { of AGOA }\end{array}$ & 0 & 0 & 0 & 0 & 0 \\
\hline US imports under GSP from Kenya & 0 & 0 & 0 & 0 & 0 \\
\hline $\begin{array}{l}\text { US imports of duty-free items added } \\
\text { under AGOA }\end{array}$ & 0 & 0 & 0 & 0 & 0 \\
\hline \multicolumn{6}{|l|}{ All sectors: } \\
\hline US exports to Kenya & 267,972 & 193,009 & 386,938 & 276,896 & 537,581 \\
\hline US imports from Kenya & 189,156 & 249,137 & 352,165 & 163,965 & 174,395 \\
\hline $\begin{array}{l}\text { Total AGOA including GSP provisions } \\
\text { of AGOA }\end{array}$ & 129,210 & 184,441 & 286,688 & 131,773 & 135,120 \\
\hline US imports under GSP from Kenya & 4873 & 3842 & 6790 & 2855 & 2129 \\
\hline $\begin{array}{l}\text { US imports of duty-free items added } \\
\text { under AGOA }\end{array}$ & 124,337 & 180,599 & 279,898 & 128,918 & 132,991 \\
\hline
\end{tabular}

Source: Calculated from US Department of Commerce and AGOA (2005).

Appendix 2: US tariff rates for selected items of clothing, 2003

\begin{tabular}{|c|c|c|}
\hline Tariff sub-heading & Article & Rate of duty (\%) \\
\hline \multicolumn{3}{|c|}{ Ch. 61 - Articles of apparel and clothing accessories, knitted or crocheted } \\
\hline 6109.10 .00 & Cotton T-shirts & 17.0 \\
\hline 6109.90 .10 & T-shirts of man-made fibres & 32.2 \\
\hline 6111.20 .60 & Babies' cotton knit sun suits & 8.2 \\
\hline 6115.92 .90 & Cotton socks & 13.6 \\
\hline \multicolumn{3}{|c|}{ Ch. 62 - Articles of apparel and clothing accessories, not knitted or crocheted } \\
\hline 6203.42 .40 & Men's cotton trousers or shorts & 16.7 \\
\hline 6204.52 .20 & Women's cotton skirts & 8.2 \\
\hline 6204.43 .40 & Women's synthetic fabric dresses & 16.1 \\
\hline 6205.20 .20 & Men's or boys' cotton shirts & 19.8 \\
\hline 6206.40 .30 & Women's or girls' blouses of man-made fibres & 27.1 \\
\hline 6207.21 .00 & Men's or boys' cotton pyjamas & 9.0 \\
\hline
\end{tabular}

Source: Calculated from Harmonised Tariff Schedule of the United States (2003, Supplement 1). 